ported by many museums and research institutions worldwide.

"Many people are focusing their support on Diversitas as an all-embracing initiative," says Steve Blackmore, keeper of botany at the Natural History Museum in London. Prance, who chairs Diversitas, says that what sets it apart from other conservation initiatives is that it exists only to "promote and co- ordinate research on biodiversity". Diversitas already plays an important role in co-ordinating the activities of museums and other research institutions internationally. It has set up working groups to assess the state of knowledge, identify gaps, and reach international consensus on priorities for taxonomic research - for example on groups of organisms that should be targeted.
One of those who endorses the need for a coordinated international approach is Dennis O'Connor, provost of the Smithsonian Institution in Washington, DC. "It is going to be very important for the organizations involved in systematic biology to talk about what their priorities are, and how they all can participate," he says. "We won't get there by conducting business as usual."

\title{
Core missions under growing pressure
}

The demands of biodiversity research are leading to a new assertiveness among museums that they should be respected as places of scholarship uniquely well placed to pursue a holistic, multidisciplinary approach to fundamental research on the Earth and its biosphere.

Broadly, natural history museums have three core missions: conservation of collections, public understanding, and research. Museum research is distinguished from that carried out in universities by the fact that it is built around the collections.

But this specialized role has long been vulnerable to two sets of pressures. One is the need to seek research funds from outside agencies whose goals are often very different from those of museums. The other is the desire of funders - and often of museum management, acting at their behest - to devote resources to meet the public's demand for increasingly costly, blockbuster, theme-park style exhibitions.

"It must be recognized that building attendance and developing strong programmes in collections and research are not mutually exclusive," says Peter Crane, director of the Field Museum in Chicago. "The great natural history museums will not survive if collections and their associated research become peripheral to their future."

The Muséum National d'Histoire Naturelle in Paris has recently been criticized, in a report by an interministerial committee, for failing to assert its core missions sufficiently. These are to create an inventory of biodiversity using the techniques of systematics, genetics and molecular biology; to study the evolution of man and the biosphere; and to promote understanding of the environment. The report complains that researchers at the museum employed or funded by external agencies, such as the Centre National de la Recherche Scientifique, are assessed not on their contribution to the museum's missions, but solely on the basis of their publication record.

This narrow assessment has led researchers to pursue work that is often distant from the museum's core missions, says the report. It has also resulted in a neglect of collections-based research and curatorship. The report calls for new statutes that define clearly the allegiances of researchers funded by external agencies, and ensure that external bodies take into account the specialized role of museum researchers, and their contribution to the museum's missions.

Henry de Lumley, the museum's director, contests this analysis, arguing that the museum's modern research laboratories fulfil an important logistical role within the institution. But he agrees that there has been an overemphasis on medical research in some labs, and that funding agencies have in the past placed excessive emphasis on molecular biology projects, for example, at the expense of systematics and whole-organism biology.

Quentin Wheeler, from Cornell University, New York, a former president of the Association of Systematic Biologists, says he accepts that molecular biology and other modern disciplines are essential to a museum's activities. But he says that the overriding need of cash-strapped museums to find funds has often resulted in the growth within them of research areas that have little relevance to evolution or systematics.

Rather than asserting their core missions, Wheeler says museums have tended "to follow the orientations of outside grant agencies and universities; like moths on a pheromone trail, they see the dollar signs". He argues that many museum researchers are doing work that could be carried out at any university, such as medically-oriented research on natural products.
Even within core museum research areas such as systematics, tensions often run high between traditional and modern sciences. "Our local molecular lab has damn little to do with any of the museum systematicists; furthermore, they compete for space, fellowships, and funding," protests Victor Springer, Axelrod Curator of Fishes at the Smithsonian Institution's National Museum of Natural History in Washington, DC.

Much of such antagonism can be traced to resentment by traditional systematicists at the high costs of such facilities as DNA sequencing laboratories, when they have few funds to maintain their collections, argues Edward Theriot, director of the Texas Memorial Museum in Austin.

Theriot is both a museum administrator — "with a responsibility to seek opportunities for support" - and president of the Association of Systematics Collections. He admits that museums face a difficult task in balancing the need to be involved in cuttingedge research, such as molecular systematics, with their duty to carry out research based around their collections.

But, in opposing molecular biologists, traditional systematicists are "attacking the wrong enemy", argues Theriot. He says the overriding need is to attract greater funding for biodiversity research, and that "better marketing" by the systematics community would be a more constructive step towards this goal.

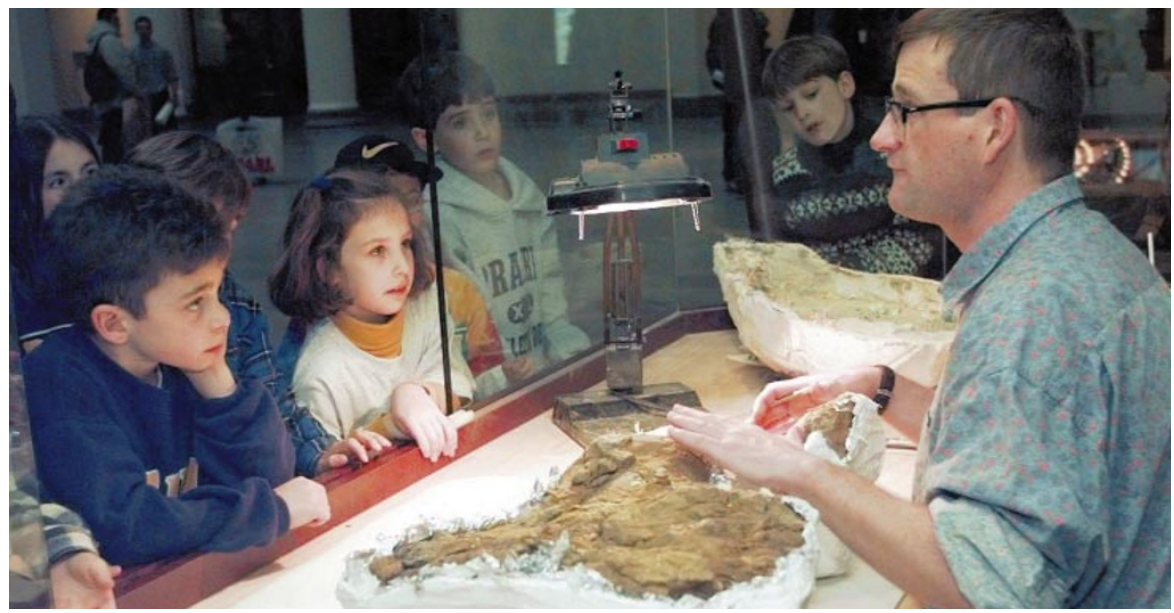

Window on research: children visiting Chicago's Field Museum watch Steve McCarroll prepare for display a pelvis bone from Sue, the most complete Tyrannosaurus rex ever discovered. 